\title{
DEVELOPING LEARNING MEDIA BASED ON AUGMENTED REALITY (AR) TO IMPROVE LEARNING MOTIVATION
}

\author{
Ridho Dedy Arief Budiman,M.Pd ${ }^{1)}$ \\ ${ }^{1)}$ IKIP PGRI Pontianak, Pontianak, Indonesia \\ E-mail: ridho.asytarrazi@gmail.com
}

\begin{abstract}
This research aims to reveal the development of Augmented Reality-based learning media to increase motivation to learn computer assembly materials. This research is an research and development type. The population was ninth students of SMP Harapan Ananda Kubu Raya totaling 112 students. The sample was 68 students with proportional random sampling technique. Data Collection using a questionnaire. To test the hypothesis, one-tailed t-test was used. Data analysis was performed descriptively. The results showed that one-tailed t-test data is posttest questionnaire motivation experimental class and control sig $0.000<\alpha 0.05$, so it can be concluded that the motivation to learn the experimental group was higher than the control group.
\end{abstract}

Keywords: Augmented Reality, Learning Motivation

\section{INTRODUCTION}

Education is basically the process of the development of the potential learners. In the implementation of education in schools that involve teachers as educators and students as learners, realized with the teaching and learning interaction or learning process.

Education aims to help people in developing himself and able to deal with all the changes and problems with an open attitude and creative approach without losing identity. Therefore, every moment from the teaching process is designed and organized to be able to contribute concretely to the achievement of the purpose of education. In the present the sophistication and progress of technology can be used in the field of education, therefore there is a need for new innovations to create a quality learning media, this further encourages the efforts of reforms in the utilization of the results of technology in the learning process.

In the digital world especially computer technology the development rapidly forcing the wearer to always adjust with the existing development. The computer that is identical with the virtual world can now be presented side by side in the real world. This technology called Augmented Reality (AR). This technology will continue to be developed and integrated into the real world to visualization displayed more interesting so that it can be used as a teaching tool to support the learning process.

By implementing creative and innovative lessons by the teachers will be able to help increase the motivation of students to more vigorously and with easy to understand what is learned. According to the Nazarite, Rizvi \& Pujeri (2012) "The Use of learning media in the learning process can motivate students to learn and more easily get information".

The results of the survey in the SMP Harapan Ananda Kubu Raya, on the skills subjects used by the teachers to give the material the assembly of the computer to the students especially the grade IX, after doing interviews on the teachers and the students of grade IX especially in the subject skills obtained the describing that the learning process that happens is still using the method of lectures so that the teacher is very dominate the learning and interaction between the teachers and the students less dynamic. Teaching aids used is also not in accordance with the number of students available so that the teachers are also occasionally take advantage of the printed media such as books packages that are available in the library. The condition makes the students less motivated, this visible less existence and enthusiastic response of students in learning especially in the assembly of the computer material, because on this material students need the simulation. It is also known that learning media based on augmented reality as teaching materials in the SMP Harapan Ananda has never been used.

Based on the explanation above, the researchers develop learning media based on augmented reality that will help the students learn actively to improve motivation to learn on materials the assembly of the computer. Learning Media consists of your module and an application extension. an apk that can install on your Android. So that students not only get the material in the school but can repeat the material outside the school using only the smart phone which possesses, remember today smart phone not more expensive goods and difficult to be found. To develop the assembly of the computer module as supporters is expected to increase the motivation of students in learning, especially on materials the assembly of the computer.

\section{LITERATURE REVIEW}

\section{A. Learning Media based on Augmented Reality (AR)}

Learning Media is part of the learning tools that have an important role in the process of the subjects. Smaldino, 
Lowther, Russell (2002, p.362) states that: "medium, a means of communication. Derived from the latin medium ("between"), the term refers to anything that carries information between a source and receiver". A similar opinion was also expressed by Sudjana and Rivai (2013) stating that the teaching of the media is a teaching tool that is in the components of the teaching methodologies, as one of the learning environment that is regulated by the teacher.

Augmented Reality (AR) is a technology that combines objects maya two dimension or three-dimensional into a real environment three dimensional and then projecting the virtual objects in real time (Valino, 1998). According to the explanation of the Haller, Billinghurst, and Thomas (2007), Research Augmented Reality aims to develop technology that allows the merger in real-time against digital conten made by the computer with the real world. Augmented Reality allows users to see maya objects two or threedimensional which is projected to the real world. (Emerging Technologies of Augmented Reality: Interfaces and Design).

Maad. (2010, p.3) stated that "Augmented Reality is a system that supplements the real world with computergenerated virtual objects, is seem to coexist in the same space and present the services as following properties (Bimber, 2005)(Azuma, 2001): (a) It combines real and virtual objects in real environment; (b) It executes interactively in real time; (c) It lines up real and virtual objects; (d) It is applied to all has been of the user".

So it can be interpreted that Augmented Reality is a system that is complete the real world with the virtual object that produced the computer, which seems to live side by side in a same space and presents the following properties (Bimber, 2005) (Azuma, 2001): (1) This combining tangible objects and maya in real environment; (2) Is executing interactively in real time; (3) This line tangible objects and virtual; (4) This is applied to all the senses of the user.

From the explanation above can be deduced learning media based on augmented reality is a teaching tool that uses technology to combine objects maya two dimension or threedimensional into a real environment to convey an information to support the learning process.

\section{B. The Working Principles of Augmented Reality}

According to Fernando (2013, p.3) Augmented Reality work using the technique of computer vision and technique of pattern recognition. The technique of computer vision is a technique in which the system to search for the card (marker). While the technique of pattern recognition is a technique to identify the pattern. It means the system will identify the marker from the application of the first. If the system has been identifying marker then the system will display the object that is in accordance with the marker that has been known previously.

According to Prihantono (2013, p.1) the working from the application of the Augmented Reality i.e. when markers which is already known from the application is detected by the camera then the result will display the object 2D and 3D is displayed in the screen monitor. The results of the conjunction real situations and maya displayed in interactive and realtime services.

Based on explanation can be concluded that the working principles of Augmented Reality is the system will read the marker that has previously created. When the system has been successfully read marker is then the system will display the object in accordance with the marker that has made before. The object is shown in the picture $2 \mathrm{D}$ and $3 \mathrm{D}$ and video.

\section{Lessons Subject for the Assembly of the Computer}

SMP Harapan Ananda Kubu Raya mentioned in the skills subject used to give the skills deemed useful for the students especially the students of grade IX namely assemble and install the operating system on the basis of personal computer.

The material the assembly of the computer has two main subjects that will be studied, namely: (a) types of equipment/ component on the PC and each specification. (b) The steps the assembly of the computer and the procedures and safety at assemble the computer.

\section{Learning Motivation}

Schunk, Pintrich \& Meece (2010, p.4) define "Motivation is the process whereby goal-directed activity is instigated and sustained". The motivation is a process than a product. As a process, motivation inferred from action. The motivation involves the purpose of that give encouragement and direction for action. According to Woolfolk (2007, p.372) motivation is a state of in themselves that can raise, directs, and observe the behavior of the individual. The motivation can be created through the self-consciousness or that comes from within themselves (intrinsic motivation) and through encouragement from other people and the environment (extrinsic motivation components).

The motivation has an important role in the learning process. The motivation determines all things that can be used as an intensifier in learning. The motivation can clarify learning goals that you want to reach a man. Motivation to determine the various control of learning stimuli. The motivation can also determine learning endurance.

\section{RESEARCH METHOD}

\section{A. Research Model}

This research model is reseach and development (R\&D). The development of this product is expected to increase the motivation of student learning. While the results or products in research and development of this is to get a new product in the form of software namely android application (.an apk) learning.

\section{B. The Time and Place of Research}

This research conducted on May 2016 in SMP Harapan Ananda Kubu Raya. SMP Harapan Ananda address in Supadio arterial roads, Komp. Pondok Indah Lestari, Kubu Raya, West Kalimantan. 


\section{The Population and Research Sample}

The research population is students SMP Harapan Ananda Kubu Raya Grade IX of second semester fulfilled 2015/2016 school year. The Grade IX is divided into three classes, namely Grade IX A, IX B and IX C. The Grade IX A numbered 34 students, Grade IX B amounted to 34 students and Grade IX C amounted to 34 students, so that the total is 112 students.

Based on the research design, needed two classes of samples is one class groups of experiments and one class control group. One other class is used as the class test.

Before defining the class as a sample of the test done homogenitas first semester values in order to know whether the variants of a sample of the Grade IX. If the members of the population is homogeneous, then the samples in this research in take with the random sampling technique, namely with shake selected class list so that members of the population have a probability or the same opportunity to in select a sample. Then assign the new class that will be used in this research are the students of Grade IX SMP Harapan Ananda teachings years 2015/2016 that consists of 2 class which is Grade IX A as control classes and Grade IX B as class experiment.

\section{Research Design}

Research experiment using Pretest-Posttest design Control Group Design as Table 1 :

TABLE 1

RESEARCH DESIGN PRETEST-POSTTEST CONTROL GROUP DESIGN

\begin{tabular}{cccc}
\hline Samples & $\begin{array}{c}\text { The } \\
\text { Beginning } \\
\text { Condition }\end{array}$ & $\begin{array}{c}\text { The } \\
\text { treatment }\end{array}$ & $\begin{array}{c}\text { The End } \\
\text { condition }\end{array}$ \\
\hline $\begin{array}{c}\text { The Experiment } \\
\begin{array}{c}\text { Class } \\
\text { The Control } \\
\text { Class }\end{array}\end{array}$ & $\mathrm{O}_{1}$ & $\mathrm{X}$ & $\mathrm{O}_{2}$ \\
\hline
\end{tabular}

In this design there are two groups who selected by random, then given pretest to'll see original condition are there any differences between the group of the experiment and control groups. Good pretest results when the value of the group of the experiment did not difference significantly.

\section{E. The Data Collection Technique}

The observation is used to collect data during the process of needs analysis. Researchers conducting pre survey on the students of Grade IX on the skills subject matter the assembly of the computer in the SMP Harapan Ananda Kubu Raya. Researchers doing interviews on students and teachers then provide questionnaires needs of teachers.

\section{F. Data Collection Instrument}

This research uses the research instrument in the form of questionnaires in the data collection. There are six the use of the structure of the questionnaires used researchers, namely: (a) questionnaires to measure the feasibility according to the experts of matter, (b) questionnaires to measure the feasibility according to media expert, (c) questionnaires to measure the feasibility of media according to teachers (d) questionnaires to measure the feasibility according to user (students), (e) the pretest questionnaires measuring student motivation to learn, (f) the posttest questionnaires measuring student motivation with media ar, (g) the posttest questionnaires measuring student motivation with books media.

\section{G. Data Analysis Techniques}

Data analysis techniques used to know the level of student learning motivation of learning media materials the assembly of the computer is descriptive statistics with a percentage. Descriptive statistics is part of the statistics function to collect data, determine the statistics values and the making of the diagram or graph on a matter so easy to read and understood.

Hypothesis test using the SPSS 23 program Paired Sample $t$ test on the value of the pre test - post test class experiment and pre test - post test control classes with equal to the significance of 5\%. This test is used to know the difference between the average value before given treatmen (pre-test) with the average value after given treatmen (posttest) with the use of learning media based on Augmented Reality.

\section{RESEARCH RESULT}

The The result of the validation of learning media by media experts can be seen the assessment of the media aspects including category is very good overall score from the aspect of effectiveness, attractiveness, efficiency utility and logic some 76 and score an average of 3.8 including in the category of "very good".

The result of the validation of learning media by experts in the matter can be seen the assessment of aspects of the material including category is very good, overall score from the contents aspects of a number of 74 and score an average of 3.7 including in the category of "very good".

The result of the validation of learning media by teachers can be seen the results of the assessment of media aspects including category is very good overall score from the contents aspects, the learning aspects, the effectiveness aspects, the attractiveness aspects, the efficiency aspects, the benefit aspects and the logic aspects of some 148 and score an average of 3.7 including in the category of "very good".

Product test done to know the product quality, is that worthy to be used more broadly. At this stage done trial through questionnaires covered that consists of 21 statement to 32 respondents Grade IX C. 
The percentage of score trend on data the results of the test the use of media products can be presented in the form of a circle diagram, which can be seen in fig 1 .

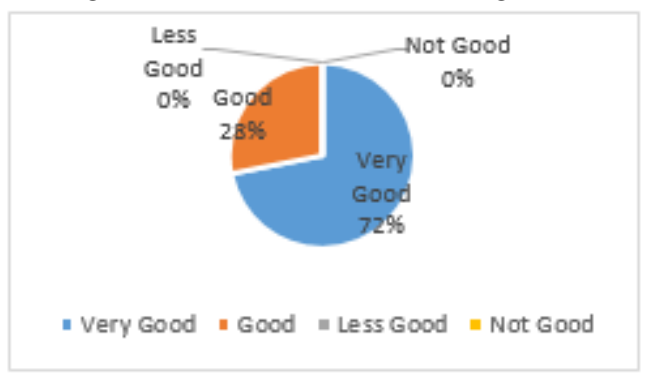

Fig 1. Circle Diagram Percentage the Results of Data Testing the use of Media Products

Based on the results of the calculation of the category the tendency of the score test results data the use of media products, in general can be said that the trial use of media products including in the category of "very good" with large percentage is $72 \%$.

\section{A. Data Analysis}

1. The Prerequisites Test of Experiment and Control Class

a. Normalitas Test

The Data stated normal distribution when the significance value greater from $0.05(\mathrm{P}>0.05)$. The results of normality test data results research can be seen in table 2 .

TABLE 2

THE NORMALITY TEST RESULTS

\begin{tabular}{lcc}
\hline \multicolumn{1}{c}{ The variables } & Sig. & Explan. \\
\hline $\begin{array}{l}\text { Pre-test Motivation Grade } \\
\text { IX A }\end{array}$ & 0,200 & Normal \\
$\begin{array}{l}\text { Pre-test the Motivation } \\
\text { Grade IX B }\end{array}$ & 0,188 & Normal \\
$\begin{array}{l}\text { Post-test Motivation and } \\
\text { control classes }\end{array}$ & 0,155 & Normal \\
$\begin{array}{l}\text { Post-test Motivation to the } \\
\text { learning Class Experiment }\end{array}$ & 0,173 & Normal \\
\hline
\end{tabular}

\section{b. Homogenity Test}

Homogenity test is intended to show that two or more groups of sample data is derived from the population that have the same variansi. The calculation of the homogenitas test using the software SPSS 23 with Levene statistics test with the results can be seen as follows:

TABLE 3

THE HOMOGENITY TEST RESUlTS

\begin{tabular}{lcc}
\hline \multicolumn{1}{c}{ The variables } & Sig. & Explan. \\
\hline $\begin{array}{l}\text { Pre-test Motivation } \\
\text { experiment and }\end{array}$ & 0,352 & Homogeneous \\
Control Class & & \\
\hline
\end{tabular}

c. Similarity Tests the Two Average
Similarity tests the two average data pretest aims to know the common early ability students in each group. The similarity test the of two average pretest data on experiments class and control classes using independent samples test that mingled with the help of the program SPSS 23, can be seen as follows:

TABLE 4

THE RESUlts OF THE SimILARITy OF Two AveragE

\begin{tabular}{lcc}
\hline \multicolumn{1}{c}{ The variables } & Sig. & Explan. \\
\hline $\begin{array}{l}\text { Pre-test Motivation } \\
\text { experiment and Control } \\
\text { classes }\end{array}$ & 0,105 & $\begin{array}{c}\text { The same } \\
\text { average }\end{array}$ \\
\hline
\end{tabular}

\section{The Final Phase of the Data Analysis Results}

a. Analysis of Questionnaires the Motivation of Student Learning

\section{1) Pretest Data Descriptive}

The percentage of the tendency of the score on the pretest data motivation students learning can be presented in the form of a circle diagram, which can be seen in the picture below:

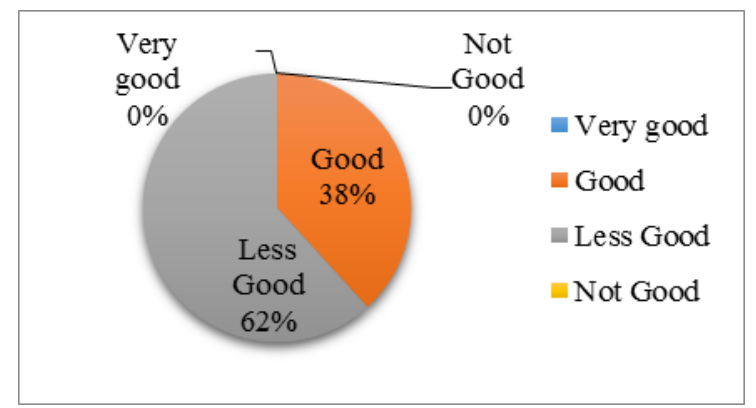

fig 2. The Circle Diagram Percentage of Pretest Student Learning Motivation Grade IXA

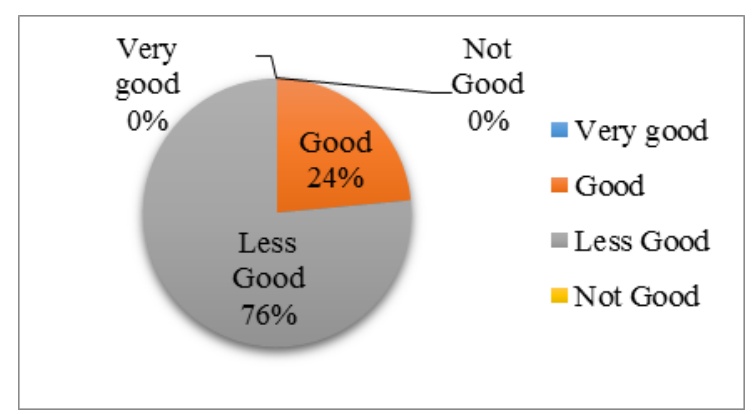

fig 3. The Circle Diagram Percentage of Pretest Student Learning Motivation Grade IXB

Based on the results of the calculation of the category of the tendency in the pretest score motivation to the students learning of class IXA in general it can be said that the learning motivation including in the category of less well with large percentage is $62 \%$. While the results of the calculation of the category of the tendency in the pretest score motivation to the students learning of class IXB in 
general it can be said that the learning motivation including in the category of less well with large percentage is $76 \%$.

\section{2) The Descriptive of Posttest Data}

The percentage of the tendency of the score on posttest data the students learning motivation can be presented in the form of a circle diagram, which can be seen in the picture below:

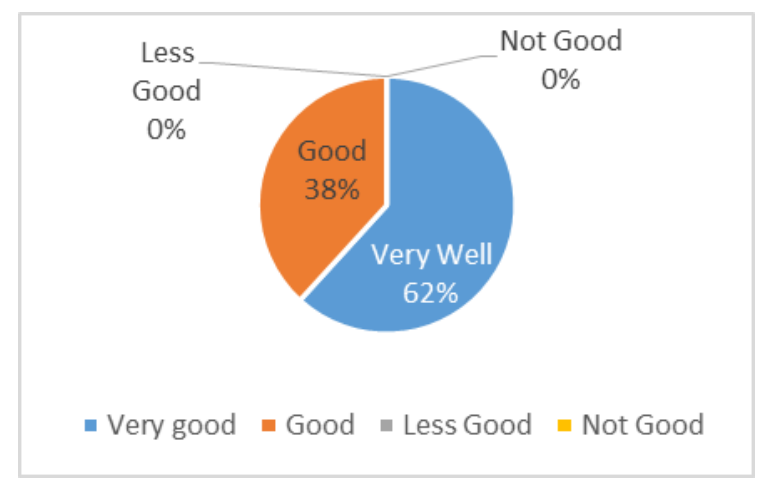

Fig 4. The Circle Diagram the Percentage Posttest Learning Motivation of Experiment Class

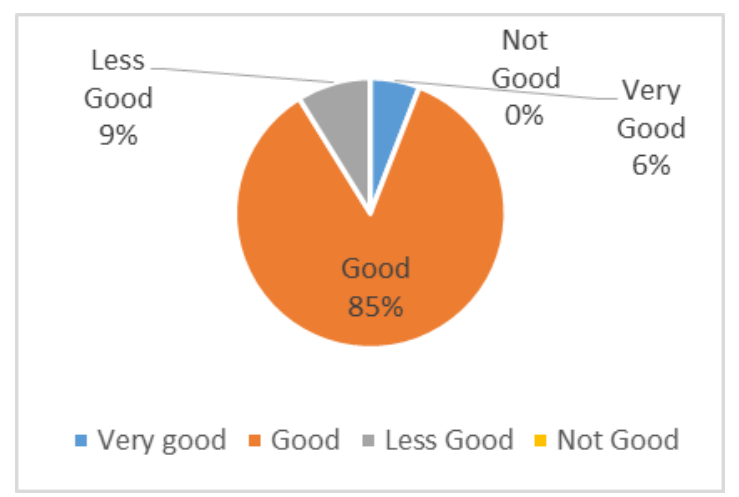

Fig 5. The Circle Diagram Percentage Posttest Learning Motivation of Control Class

Based on the results of the calculation of the category of the tendency in the posttest score motivation to the learning students of class experiment in general it can be said that the learning motivation including in the very good category with large percentage is $62 \%$. While the results of the calculation of the category of the tendency score in the posttest student learning motivation the control class in general it can be said that the motivation to learn including in the good category with large percentage is $85 \%$.

\section{B. The Hypothesis Test}

The Hypothesis that will be tested:

Ho: The Student learning motivation that utilizing learning media based on Augmented Reality is lower or the same with the students learning motivation that utilizing of the book media on materials the assembly of the computer the students of Grade IX SMP Harapan Ananda.

Ha: The Student learning motivation that utilizing learning media based on Augmented Reality higher than the
Student learning motivation who take utilizing of the book media on materials the assembly of the computer the students of Grade IX SMP Harapan Ananda.

TABLE 5

THE RESUlts OF THE INDEPENDENT TEST SAMPLE TEST (T TEST) MOTIVATION OF EXPERIMENT AND CONTROL GROUP

\begin{tabular}{cccc}
\hline The Group & $\alpha$ & Sig. & Description \\
\hline $\begin{array}{c}\text { The Experiment } \\
\text { class }\end{array}$ & 0.05 & 0,000 & Ho rejected \\
$\begin{array}{c}\text { The Control } \\
\text { Class }\end{array}$ & & & \\
\hline
\end{tabular}

According to the data on the table above and the results of the data analysis it is known that the significance value that obtained is 0,000 . The significance value is smaller than the value of $\alpha$ namely $0,000<0.05$ so that the Ho was rejected and $\mathrm{Ha}$ accepted. Thus it can be concluded that the student learning motivation that utilised learning media based on Augmented Reality higher than on the student learning motivation that utilised the book media on materials the assembly of the computer the students of Grade IX SMP Harapan Ananda Kubu Raya.

\section{THE CONCLUSIONS AND RECOMENDATIONS THE HoMOGENITY TEST RESUlTS}

\section{A. Conclusions}

The conclusions from this research is: (1) Developed through three phases include planning phase, development and evaluation. The results of this development research is a product of learning media the assembly of the computer based on the Augmented Reality that is installed on the system android (.apk) and the module as supporters; (2) Test results in one party (one tail test) reachable t values count is greater than the value of the t table namely 6,322 > 1,670 so that the Ho was rejected and Ha accepted. Thus it can be concluded that the student learning motivation that utilizing of learning media based on Augmented Reality higher than on the learning motivation that utilizing of the book media on materials the assembly of the computer the students of Grade IX SMP Harapan Ananda Kubu Raya.

\section{B. Suggestions}

A few suggestions that can be served from this research is: (1) The products of learning media the assembly of the computer based on the Augmented Reality this could be applied to schools that allow students bring cellphones to school; (2) Media can be developed more on the other subjects in order to increase the motivation of student learning can occur in the classroom, the students and the other subjects; (3) This research is still limited to one school in SMP Harapan Ananda Kubu Raya, so that further research needs to be done on a large scale and expanded on some good schools in one district and in some provinces to provide ratings on the quality of learning media products based on Augmented Reality.

\section{REFERENCES}


[1] Azuma, R. T. (1997). A Survey of Augmented Reality. Presence: Teleoperators and Virtual environments.

[2] Fernando, M. (2013). Create an application Android Augmented Reality Using Vuforia SDK and at Unity. Solo: AR Book Online.

[3] Haller, M., Billinghurst, M., \& Thomas, B. H. (2007). The emerging Technologies of Augmented Reality: Interfaces and Design.

[4] Maad, S. (2010). Augmented Reality. India: Intech.

[5] The Nazarite, Jawid, Rizvi, Aftab Haider \& Pujeri, R. (2012). Skill development in multimedia based learning environment in higher education: s operational Model. International Journal of information and communication technology research. 2(11).

[6] Dwita S. Prihantono, D. (2013). Create a Game application 3D Interactive Augmented Reality. Solo: AR Book Online.
[7] Schunk, D. H., Pintrich, P. R., \& Meece, J. L. (2010). Motivation in education: Theory, research, and applications (3rded). Trenton: Pearson Education, Inc.

[8] Smaldino, S.E., Heinich, R., Molenda, M., \& Russell, Indonesia Customer Satifaction Index Study (2002). Instructional Tecnology and Media for Learning (9th ed). New Jersey: Pearson.

[9] Sudjana, N. \& Rivai, A. (2013). The teaching of the Media. Bandung: New Rays Algansindo.

[10] Vallino, J. R. (1998). Interactive Augmented Reality. Rochester, New York: University of Rochester.

[11] Woolfolk, Anita. (2007). Educational psychology. Boston: Pearson International Edition. 